\title{
Kokil Kalıp Dökümde Alüminyum Alaşımların Beslenmesi Üzerinde Kalıp Ön Isıtma Sıcaklığının Etkisinin Araştırılması ${ }^{1}$
}

\author{
Murat ÇOLAK ${ }^{1}$, İbrahim ARSLAN ${ }^{2 *}$ \\ ${ }^{1}$ Bayburt Üniversitesi, Mühendislik Fakültesi, Makina Mühendisliği, Bayburt, Türkiye \\ ${ }^{2}$ Bayburt Üniversitesi, Teknik Bilimler Meslek Yüksekokulu, Mülkiyet Koruma ve Güvenlik Bölümü, Bayburt, \\ Türkiye
}

\begin{abstract}
$\ddot{\mathbf{O} z}$
Döküm, tekrar kullanılabilir kalıplar kullanarak geometrik olarak karmaşık metal parçalar üretebilen bir süreçtir. Kalıp döküm yöntemi pahalı bir yöntem olduğundan, seri üretim için tercih edilir, ancak karmaşı ve küçük parçaların dökümünde yüksek kaliteli bir sonuç verir. Kalıplanmış döküm, alüminyum gibi düşük sıcaklıklarda çok sayıda eritilmiş malzemeden yapılabilir. Üretilen parçaların yüzeyleri, işleme gerektirmeyen temiz ve kalitelidir. Kalıp 1sı transfer katsayısı kum kalıbından çok daha yüksek olduğu için, soğutma daha hızlı gerçekleşir ve porozitesiz katı parçaların üretilmesi için birçok faktör dikkate alınır. Kalıp ön ısıtma sıcaklığı, kalıp döküm yöntemindeki besleme durumunu doğrudan etkiler. Bu çalışmada, alüminyum alaşımların kalıp ön ısıtma sıcaklığının kalıba dökülme üzerindeki etkileri araştırılmıştır. Bu amaçla, özel olarak farklı kesit kalınlıkları olan bir model tasarımı gerçekleştirilmiştir. Döküm çalışmalarında Etial 110, Etial 140, Etial 160 ve Etial 177 alüminyum alaşımları kullanılmıştır. Kalıp ön 1sıtma sıcaklığı, parça geometrisine bağl 1 olarak $200^{\circ} \mathrm{C}, 300^{\circ} \mathrm{C}$ ve $400^{\circ} \mathrm{C}$ olarak belirlenmiştir. Numunelerin beslenme durumu makroskopi, aritmetik prensip ve yoğunluk ölçümleri ve kesit yüzey incelemeleri ile değerlendirildi. Elde edilen sonuçlar değerlendirildiğinde, sıcaklık artışının, alaşımlamaya bağlı olarak değişen oranlarda beslemeyi olumlu yönde etkilediği gösterilmiştir.
\end{abstract}

Anahtar Kelimeler: Alüminyum alaşımları, Kokil kalıp, Besleme, Kalıp tasarımı, Kalıp sıcaklığı.

\section{Investigation of Effect of Mold Preheating Temperature on Feeding on Aluminum Alloys in Die Casting}

\begin{abstract}
Die casting is the process that can produce geometrically complex metal parts using reusable molds. Due to the die casting method is an expensive method, it is preferred for mass production, but it gives a high quality result in the casting of complex and small parts. Molded casting can be made from a large number of melted materials at low temperatures (i.e. aluminum). The surfaces of the produced parts are clean and high quality and it does not require any machining process. Since the mold heat transfer coefficient is much higher than the sand mold, the cooling takes place faster and many factors are considered for manufacturing solid parts without porosity. Preheat temperature of mold directly affects the feed status in the die casting method. In this study, the effects of aluminum alloys on the feed of mold preheating temperature in die casting were investigated. For this purpose, a model design with especially different cross-sectional thicknesses were carried out. Etial 110, Etial 140, Etial 160 and Etial 177 aluminum alloys were used in casting studies. Mold preheating temperature was determined as $200{ }^{\circ} \mathrm{C}, 300{ }^{\circ} \mathrm{C}$ and $400{ }^{\circ} \mathrm{C}$ depending on the part geometry. The feeding status of the samples was evaluated by macroscopy, Archimedes' principle and density measurements and section view respectively. When the obtained results were evaluated, it was shown that the ascending of temperature positively affects the feedability at varying rates depending on the alloying.
\end{abstract}

Keywords: Aluminum alloys, Die casting, Feeding, Mold Design, Mold Temperature.

\footnotetext{
${ }^{1}$ Bu çalışmanın bir bölümü İTESDES 2018' de özet bildiri olarak sunulmuştur.
} 


\section{Giriş}

Alüminyum döküm alaşımları, yüksek mukavemet, korozyon dayanımı, yüksek termal iletkenlik, iyi işlenebilirlik, süneklik ve hafiflik gibi üstün özelliklere sahiptir. Bu özelliklerinden dolayı başta otomotiv olmak üzere birçok endüstriyel alanda kullanılmakta ve kullanımı her geçen gün daha da artmaktadır (Campbell, 2003). Alan (Alan, 2008) tarafindan hazırlanan bir raporda alüminyumun ulaşım sektöründe taşıt araçlarının üretiminde kullanılan en önemli malzemelerden birisi olduğu ve alüminyum kullanımının yaklaşık \% 25'i taşıt araçlarının üretimine ait olduğu belirtilmiştir. Taşıt araçları ne kadar hafif olursa, hareket etmeleri için daha az enerjiye gerek duyulur. Günümüzde bir otomobilde yaklaşık $50 \mathrm{~kg}$ alüminyum kullanılmaktadır. Bu sayede, yaklaşık $100 \mathrm{~kg}$ demir, çelik ve bakır malzeme tasarrufu yapılmaktadır. Yapılan hesaplar ve deneyimler sonucunda, alüminyum kullanılan bir otomobilin, yeterince alüminyum kullanılmamış bir otomobile kıyasla, ekonomik ömrü boyunca 1500 litre daha az yakıt harcadığı anlaşılmıştır. Bu durumun gerek sürücülerin akaryakıt masraflarına sağlayacağı ekonomi ve çevre sağlığı açısından atmosfere yayılan atık egzoz gazının düşürülmesi yönünden çok büyük faydası bulunmaktadır. Otobüs ve tren gibi sık sık hareket eden ve duran araçlarda, aracın hafif olması daha da fazla önem kazanmaktadır (Alan, 2008).

Alüminyum alaşımlarının döküm yolu ile imalatında diğer alaşımlarda olduğu gibi katılaşma ve kalıplama tasarımı oldukça önem arz etmektedir. Alüminyum alaşımları, sıvı halden katı hale geçiş esnasında kimyasal bileşimine bağlı hacimsel olarak \%3,5'den \% 8,5'e varan oranlarda büzülürler. $\mathrm{Bu}$ hacimsel daralmanın kalıplama tasarımında uygun yerlere gerekli ebatlarda konulan besleyicilerle tamamlanması gerekir. Hacimsel azalmanın yeterli şekilde besleyicilerle beslenememesi durumunda katılaşma sonrası yapı içerisinde çekme boşlukları meydana gelir (Sigworth, 1983). Alüminyum dökümlerinde başlıca problemlerden biri olan çekinti oluşumu birçok dökümün hurdaya ayrılmasına neden olmaktadır. Döküm parça içerisinde gözle görülmeyen mikro çekinti oluşumu da; mukavemet, süneklik, yüksek basınç altında sızdırmazlık gibi alaşımın mekanik özelliklerini azaltmakta ve alaşımın kullanım alanlarını kısıtlamaktadır. Bu sebeple kaliteli bir döküm oluşturabilmek için makro ve mikro çekintinin mutlaka kontrol altına alınması gereklidir (Sabau ve Vıswanathan, 2002; Savaş, 2005). Döküm içerisinde çekinti oluşumu; katılaşma sırasında yetersiz besleme ve sıvı metal içerisinde çözünmüş olan gazlar sebebiyle oluşabilmektedir (Kayıkcı, 2004). Sıvı metal içerisinde çözünmüş hidrojen oranı, 1sıl koşullar, sıvı metalin temizliği, sıvı metale uygulanan işlemler ve yanlış besleyici tasarımı çekme boşluğu oluşumuna etki eden en önemli faktörlerdir (Chıesa ve Mammen, 1999). Çekinti boşluğu oluşumu üzerinde alaşımın kalıp ısı transfer katsayısı ve katılaşma aralığı da büyük öneme sahiptir (Campbell, 2004). 
Bu çalışmada farklı kesit kalınlıkları ve buna bağlı farklı katılaşma süreleri içeren bir model tasarlanarak kokil kalıba 4 farklı alüminyum alaşımı (Etial 110, Etial 140, Etial 160 ve Etial 177) ile dökümler yapılmıştır. Kokil kalıp ön ısıtma sıcaklıkları kalıp geometrisi göz önüne alınarak düşük, orta ve yüksek olarak sayılabilecek 3 farklı sicaklıkta $\left(200{ }^{\circ} \mathrm{C}, 300{ }^{\circ} \mathrm{C}, 400{ }^{\circ} \mathrm{C}\right)$ gerçekleştirilmiştir. Böylece aynı model geometrisi ve aynı proses şartlarında sahip dökümlerin alaşım değişimi ve kalıp ön 1sıtma sıcaklık değişimine bağlı olarak ortaya çıkardıkları gözenek oluşumu incelenmiştir. Döküm sonuçları; makro incelemeler, kesit yüzey incelemeleri, Arşimet prensibi ile yoğunluk ölçüm değerlendirmeleri ile belirlenmiştir.

\section{Materyal- Metot}

\subsection{Model Tasarımı}

Model farklı kesit kalınlıkları bulunan, alt kısmı döküm, üst kısmı besleyici ve döküm ile besleyici arasında dar bir boğazı olan dikdörtgen prizmalar şeklinde tasarlanmıştır. Modelin üstte kalan besleyici kısmı hacim ve modül kriterine göre uygun olacak şekilde klasik mühendislik hesaplamaları sonucu belirlenmiştir. Model tasarımı yapılırken SOLIDCast döküm simülasyon programı ile modellemeler yapılmıştır. Modelleme sonuçlarına göre dökümün üst besleyici kısmında alt döküm kısmını besleyebilecek sıvı metal bulunmasına rağmen değişen ebatlarda ortadaki ince kesiminde katılaşma gerçekleştiğinde besleme yolu kapanacak ve sıvı metalin alt kısma geçişi sonlanacaktır. Böylece parçanın alt kısımlarında ölçülebilir nitelikte hata oluşacaktır. Model tasarımı geometrisi görünüşleri Şekil 1'de verilmiştir.
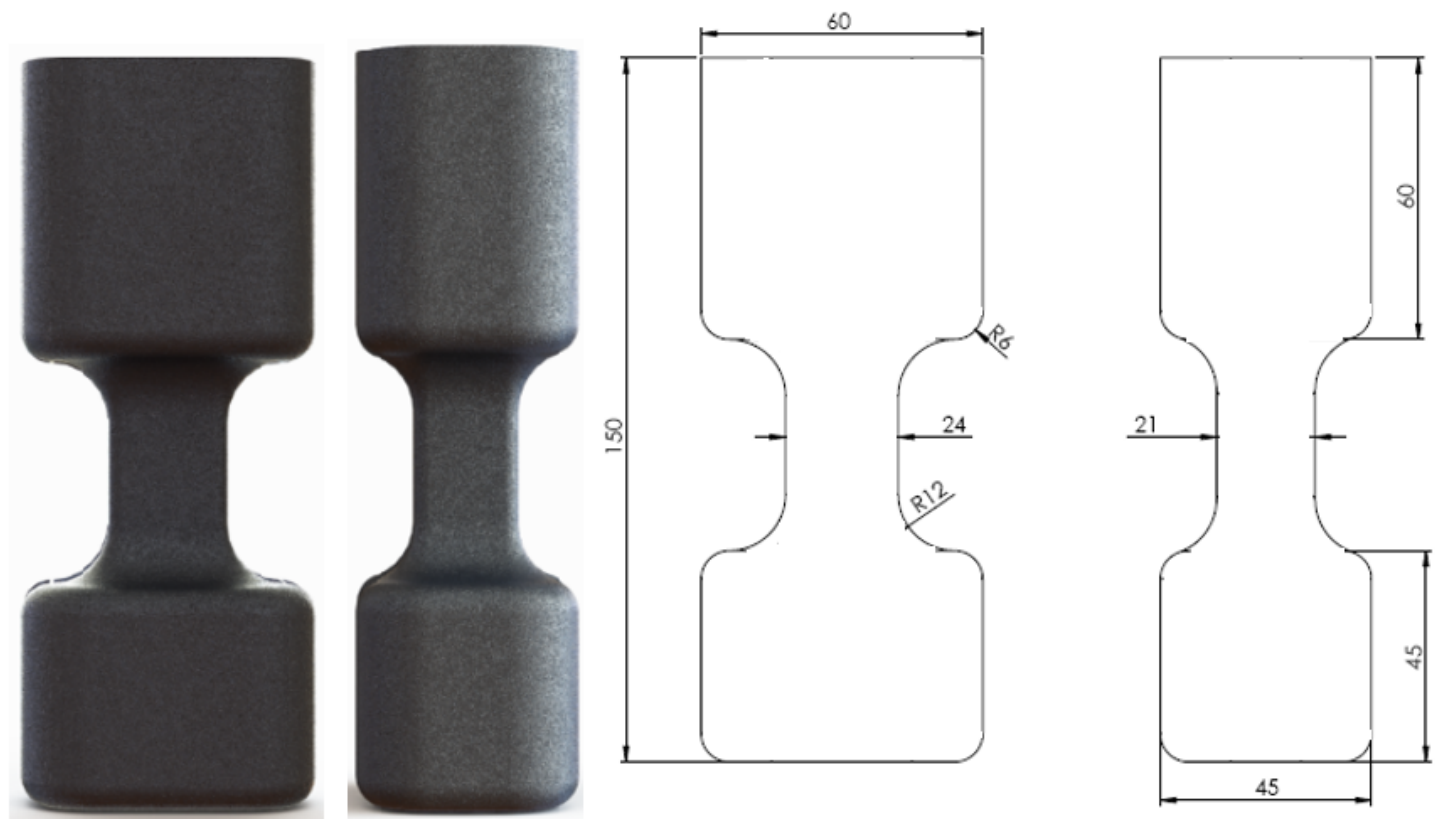

Şekil 1. Döküm deneylerinde kullanılan model ölçüleri ve kalıp görüntüsü. 


\subsection{Deney Parametreleri ve Malzeme}

Deneylerde kullanılacak alaşım seçimi yapılırken; kimyasal bileşimdeki temel alaşım elementleri, ilave miktarları, alaşım elementinin ticari olarak kullanımı göz önüne alınarak Tablo 1'de verilen alaşımlar kullanılmıştır. Alaşımlara ait spektral analiz sonucu kimyasal bileşim değerleri Tablo 1'de verilmiştir.

Tablo 1. Deneylerde kullanılan alaşımların kimyasal bileşimleri (\% A ̆g.) (URL-1, 2018)

\begin{tabular}{lcccccccc}
\hline Alaşım & Fe & Si & Cu & Mn & Mg & Zn & Ti & Sn \\
\hline Etial 110 & 0,68 & 4,87 & 3,06 & 0,42 & 0,16 & 0,18 & 0,14 & 0,04 \\
\hline Etial 140 & 0,62 & 12,42 & 0,12 & 0,46 & 0,14 & 0,08 & 0,12 & 0,06 \\
\hline Etial 160 & 0,96 & 8,24 & 3,54 & 0,48 & 0,32 & 0,86 & 0,18 & 0,12 \\
\hline Etial 177 & 0,24 & 6,96 & 0,02 & 0,04 & 0,36 & 0,05 & 0,08 & 0,04 \\
\hline
\end{tabular}

Kokil kalıba dökümde kalıp ön 1sıtma sıcaklığı ve alaşım çeşidinin porozite oluşumu üzerine etkisinin incelendiği çalışmada deney parametreleri Tablo 2'de verildiği gibi belirlenmiştir. Kalıp ön 1sıtma sıcaklıkları döküm öncesinde termokopul yardımıyla ölçülmüştür.

Tablo 2. Döküm parametreleri ve seviyeleri.

\begin{tabular}{lcccc}
\hline \multirow{2}{*}{ Faktörler } & \multicolumn{4}{c}{ Seviyeler } \\
\cline { 2 - 4 } Alaşım Çeşidi & I & II & III & IV \\
\hline Kalıp Ön Isıtma Sıcaklığı $\left({ }^{\circ} \mathbf{C}\right)$ & Etial 110 & Etial 140 & Etial 160 & Etial 177 \\
\hline
\end{tabular}

\subsection{Döküm Deneyleri}

Kokil kalıp döküm deneyleri ticari olarak faaliyet gösteren bir firmada gerçekleştirilmiştir. Kalıp bir hidrolik açma kapama presine bağlanmış ve sıvı metalin belirlenen sıcaklıkta dökülmesi, kalıbı doldurması ve katılaşma sonrası kalıpların açılması bu sistem yardımı ile gerçekleştirilmiştir. Kalıpların yüzeyleri döküm öncesinde kuru buzla temizlenmiş ve kalıp boyası ile boyanmıştır. Kalıp boyama sonrası deney parametre şartlarına uygun ön 1sıtma sıcaklığına getirilen kalıp 20 ppi seramik köpük filtre konularak kapatılmış ve döküme hazır hale getirilmiştir. Dökümler; primer külçe kullanarak deney parametrelerine uygun hazırlanan sıv1 metal azotla temizleme, cüruf alma sonrası ocaktan alınarak el potaları yardımıyla kalıp haznesine dökülmüştür. Kalıp açma süresi 5 dakika olarak belirlenmiş ve dökümden 5 dakika sonra açılan kalıp yüzeyi temizlendikten sonra diğer döküme geçilmiştir. Şekil 2'de dökülmüş bir kokil kalıp görüntüsü verilmiştir. 


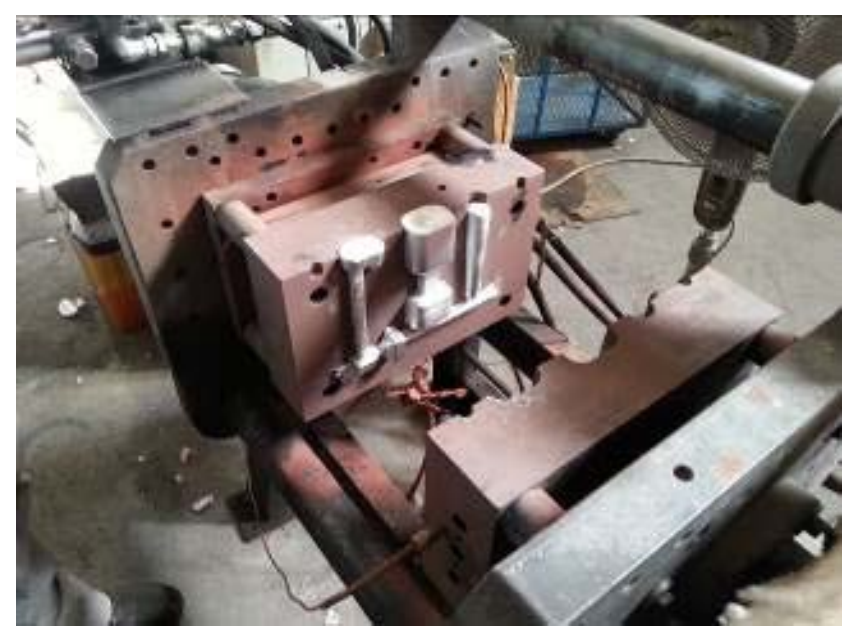

Şekil 2. Kokil kalıba döküm sonrası kalıp görüntüsü.

\section{Bulgular ve Tartışma}

Döküm numuneler kalıptan çıkarıldıktan sonra yollukları kesilmiş ve Şekil 3'de gösterildiği gibi döküm ve boğaz bağlantısı içerecek şekilde yoğunluk ölçümlerine ve kesit yüzey incelemelerine tabi tutulmuştur.
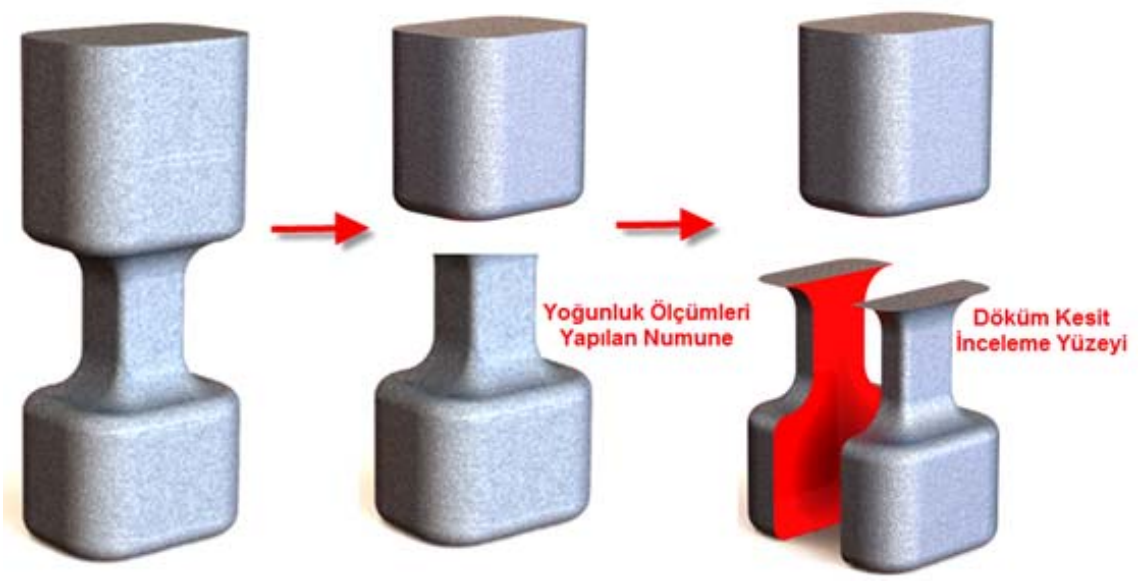

Şekil 3. Döküm numunesinin incelenmek üzere kesilen bölgesi, inceleme yüzeyi.

\subsection{Döküm numune kesit yüzey incelemeleri}

Kalıptan çıkarılan döküm parçalar, numunelerin incelenebilmesi açısından ilk olarak yolluklarından kesilerek ayrılmıştır. Döküm numunelerin makro olarak (gözle kontrol) yüzey çöküntü kontrolleri yapılmıştır. Dökümlerin yüzeyinde çöküntü olmaması iç kısımda çıkması muhtemel hataların tespiti ve ölçülebilmesi açısından önemlidir. Döküm numunelerinin yüzeyleri incelendiğinde çöküntüye rastlanılmadığı tespit edilmiştir. Döküm numunelerin kesit yüzeylerindeki gözenek durumunu incelenmek üzere, yollukları kesilen numuneler döküm ve besleme boğazını içerecek şekilde dikey olarak ortadan kesilmiştir. Kesilen numune yüzeyleri sırasıyla 180, 400, 600, 
800, 1200 gridlik SiC aşındırıcı ile zımparalanmıştır. Zımparalanmış yüzey görüntüsü taranarak görüntüler bilgisayara aktarılmıştır. Şekil 4'de kokil kalıba dökümü yapılan farklı alaşımlara ait döküm sonuçları verilmiştir. Alaşım farklılığına bağlı olarak aynı geometriye sahip kalıp içerisine yapılan dökümler sonucu kesit yüzeylerinden elde edilen porozite görüntüleri farklılık göstermektedir. Alaşımların çekinti farklılıklarının en önemli sebebi olarak katılaşma aralıkları olduğu düşünülmektedir (Campbell, 1999; Dıspınar, 2005; Schmıdt, 2010).

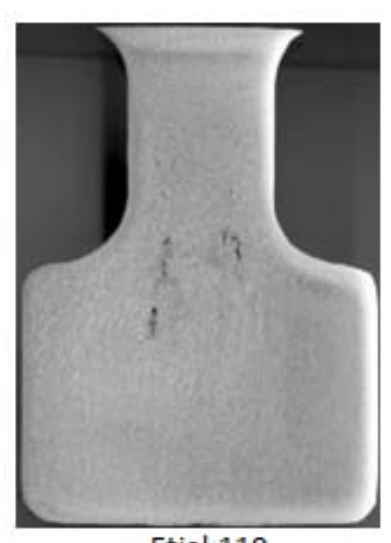

Etial 110

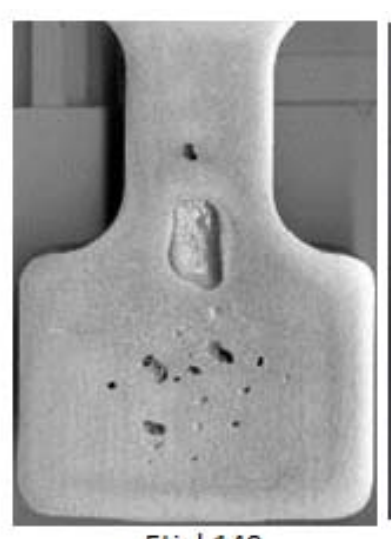

Etial 140

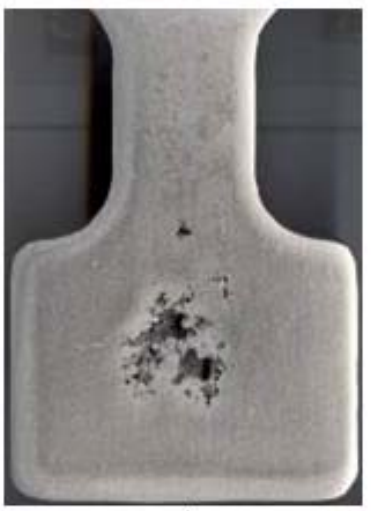

Etial 160

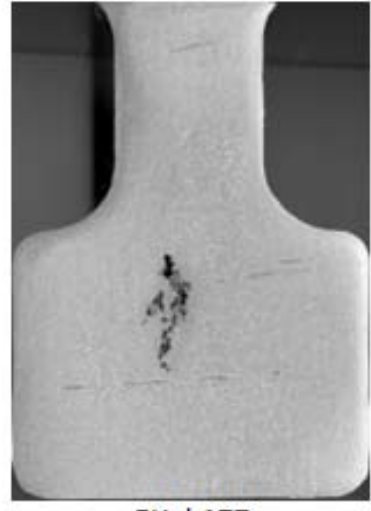

Etial 177

Şekil 4. Alaşım farklılığının kokil kalıba döküm porozite oluşumu üzerine etkisinin kesit yüzeyde incelenmesi.

Kesit yüzeydeki porozite dağılımları incelendiğinde katılaşma aralığı en geniş olan Etial 110 alaşımının yüzeyinde de çekinti miktarı gözle görülmesi oldukça güç şekilde ve çok az miktarda olduğu anlaşılmaktadır. Ancak yüzeyler stereoskopta incelendiğinde çekinti gözenekleri görülebilmektedir. \%12 Si içeren ötektik Al-Si alaşımı olan en dar katılaşma aralığına sahip Etial 140 alaşımı ise bariz bir şekilde porozite sergilemektedir. Bu alaşım bütün alaşımlar içerisinde en çok porozite gösteren alaşım olmaktadır. Etial 160 ve Etial 177 alaşımları incelendiğinde kimyasal bileşimleri farklı olsa bile katılaşma aralıklarının birbirine yakın olmasından dolayı kesit yüzeylerinde gözlenen porozite miktarları birbirine yakın seviyelerde çıktığı anlaşılmaktadır. Elde edilen sonuçlara göre alaşımların dökümünde parça içerisine alaşım farklılığının etkisinin katılaşma aralıklarına bağlı olarak değiştiği gözlenmektedir (SHAFYEI ve ark., 2006).

Kokil kalıp döküm deneylerinde ön ısıtma sıcaklığının dökümlerde porozite oluşumuna etkisinin incelenmesi için yapılan çalışmalardan alınan sonuçlara tipik bir örnek olarak Etial 177 alaşımı döküm kesit yüzey görüntüleri Şekil 5'de verilmiştir. Şekilde görüldüğü gibi kalıp ön 1sıtma sıcaklığının sırasıyla $200{ }^{\circ} \mathrm{C}, 300{ }^{\circ} \mathrm{C}$ ve $400{ }^{\circ} \mathrm{C}$ 'ye artırılmasıyla kesit yüzeylerinde görülen porozite miktarı azalmaktadır. Bu durum kalıp sıcaklığının artması ile besleme yolunun daha uzun süre açık kaldığını ve metalin alt döküm kısmını daha uzun süre besleyebildiğini göstermektedir (Akar ve ark., 2014; Danylo ve Doğan, 2008; Rav1, 2005). 

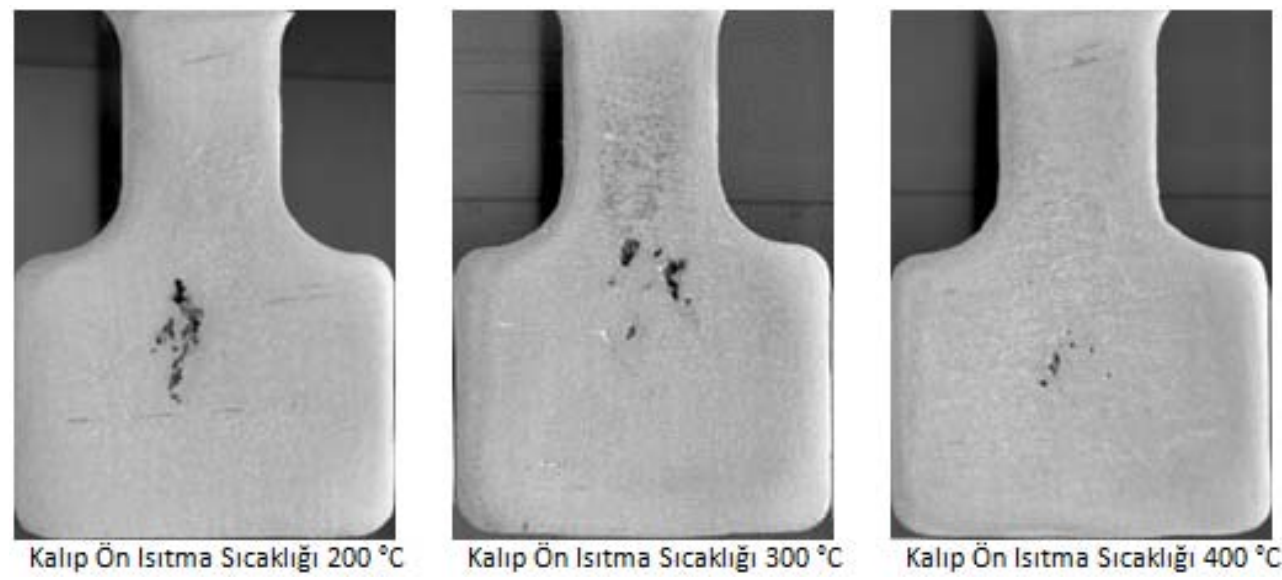

Şekil 5. Kokil kalıp ön 1sıtma sıcaklığının Etial 177 dökümünde porozite oluşumuna etkisinin incelenmesi.

\subsection{Yoğunluk ve Porozite ölçümleri}

Döküm numunelerin boşluk gözenek oranlarının sayısal olarak belirlenebilmesi ve değerlendirilebilmesi açısından yoğunluk ölçümleri Arşimet prensibine göre yapılmıştır. Numuneler döküm ve boğaz bağlantısı içerecek şekilde yoğunluk ölçümlerine tabi tutulmuştur. Belirlenen ağırlıklardan numunenin havadaki ağırlığı $\left(\mathrm{m}_{\mathrm{h}}\right)$, sudaki ağırlığı $\left(\mathrm{m}_{\mathrm{s}}\right)$, oda sıcaklığında suyun yoğunluğu $\left(d_{s}\right)$ ise döküm numunenin yoğunluğu $\left(d_{n}\right)$ olarak aşağıdaki formüle göre hesaplanmıştır. Hesaplamalarda su sıcaklığı $20^{\circ} \mathrm{C}$ 'de tartılmış ve özgül ağırlığı $0,99821 \mathrm{gr} / \mathrm{cm}^{3}$ olarak alınmıştır.

$$
\mathrm{d}_{\mathrm{n}}=\frac{\mathrm{m}_{\mathrm{h}}}{\mathrm{m}_{\mathrm{h}}-\mathrm{m}_{\mathrm{s}}} \times \mathrm{d}_{\mathrm{s}} \quad \text { (Taylor ve ark., 1999) }
$$

Numunelerin yoğunluk ölçümleri 0,02 gr hassasiyetli elektronik teraziye bağlanan bir Arşimet kiti vasıtasıyla ASTM B595-11 standardına uygun olarak yapılmıştır. Dökümlerin \% porozite değerlerinin bulunması için numunelerin yoğunluklarının alaşıma ait olması gereken tam dolu malzemenin yoğunluk değerine orantılanması Eşitlik 2'de verilen formülle tespit edilmiştir.

\% Porozite $=[($ Teorik yoğ. - Deneysel yoğ. $) /$ Teorik yoğ. $] * 100($ Dash ve Makhlouf, 2001)

Tablo 3'de kokil kalıba döküm numunelere ait yoğunluk ve porozite değerleri verilmiştir. Yoğunluk ölçümlerinden elde edilen sonuçlar kesit inceleme yöntemleri ile elde edilen sonuçlarla paralellik göstermektedir. Ayrıca bu ölçüm yönteminde porozite oranları doğrudan sayısal değer olarak ifade edilebilmektedir. Sonuçları incelediğimizde alaşım çeşidine bağlı olarak porozite miktarı değişiklik gösterdiği anlaşılmaktadır. En yüksek porozite oranı katılaşma aralığı en dar olan Etial 140 alaşımında gözlenirken en az porozite Etial 110 alaşımında gözlenmiştir. 
Kokil kalıp ön ısıtma sıcaklığının artması porozite miktarının azalmasına sebep olmuştur. Bu durum kalıp sıcaklığına bağlı olarak besleme yolunun daha uzun süre açık kalmasıyla ilişkilendirilmiştir. Ayrıca dikkat çeken bir diğer hususta porozite oranı değişimlerinin katılaşma aralığı ile ilgili olduğudur. Çünkü katılaşma aralığı geniş olan alaşımlarda porozite miktarları, katılaşma aralığı dar olan alaşımlara nazaran daha az çıkmıştır. Porozite oranları $200{ }^{\circ} \mathrm{C}$ kalıp ön 1sıtma sıcaklığında yapılan dökümlerde \% 3'e yakın iken alaşım çeşidine bağlı olarak artan kalıp ön 1sıtma sıcaklıklarında \% 1,5 seviyeleri civarına düştüğü gözlenmektedir.

Tablo 3. Kokil kalıba döküm numunelerin yoğunluk ölçümü ve gözenek değerleri.

\begin{tabular}{lcccccc}
\hline Alaşım & $\begin{array}{c}\text { Kalıp Ön } \\
\text { Isıtma } \\
\text { Sicaklığı } \\
\left({ }^{\circ} \mathbf{C}\right)\end{array}$ & $\begin{array}{c}\text { Havada } \\
\text { Ă̆ırlık }\end{array}$ & $\begin{array}{c}\text { Suda } \\
\text { Ăgırlık }\end{array}$ & $\begin{array}{c}\text { Deneysel } \\
\text { Yoğunluk }\end{array}$ & $\begin{array}{c}\text { Referans } \\
\text { Yoğunluk }\end{array}$ & Porozite \\
\cline { 2 - 7 } & 200 & 354,24 & 223,08 & 2,6960 & 2,7471 & 1,86 \\
\hline E110 & 300 & 352,48 & 222,66 & 2,7103 & 2,7561 & 1,66 \\
\hline E110 & 400 & 352,14 & 222,52 & 2,7118 & 2,7528 & 1,49 \\
\hline E110 & 200 & 343,22 & 209,14 & 2,5552 & 2,6298 & 2,84 \\
\hline E140 & 300 & 342,58 & 209,30 & 2,5658 & 2,6306 & 2,46 \\
\hline E140 & 400 & 342,96 & 209,88 & 2,5725 & 2,6331 & 2,30 \\
\hline E140 & 200 & 348,26 & 218,26 & 2,6741 & 2,7366 & 2,28 \\
\hline E160 & 300 & 347,46 & 218,42 & 2,6878 & 2,7416 & 1,96 \\
\hline E160 & 400 & 348,28 & 218,98 & 2,6888 & 2,7402 & 1,88 \\
\hline E160 & 200 & 338,24 & 207,96 & 2,5916 & 2,6618 & 2,64 \\
\hline E177 & 300 & 337,28 & 208,12 & 2,6067 & 2,6646 & 2,17 \\
\hline E177 & 400 & 337,82 & 208,94 & 2,6165 & 2,6711 & 2,04 \\
\hline E177 & & & & & & (Gram) \\
\hline
\end{tabular}

Kokil kalıba döküm deneylerinde kalıp ön ısıtma sıcaklığının gözenek oluşumuna etkisinin incelenmesi için yapılan deneylerden alınan sonuçlar Şekil 6' da ayrıca bir grafik üzerinde verilmiştir. Şekil 6'da da görüldüğü gibi, kalıp ön 1sıtma sıcaklığının artırılmasıyla birlikte dökümlerdeki gözenek miktarı azalmaktadır. $200{ }^{\circ} \mathrm{C}$ kalıp sıcaklığında en fazla gözenek içeren Etial 140 alaşımı kalıp sıcaklığının artmasıyla birlikte gözenek miktarı sırasıyla \% 2,84'den \%2,29 seviyelerine kadar düşmüştür. Ancak bu azalma miktarı daha düşük gözenek seviyelerinde oransal olarak azalmaktadır. Etial 110 alaşımında $200{ }^{\circ} \mathrm{C}$ kalıp ön ısıtma sıcaklığında \% 1,82 gözenek mevcutken, kalıp sıcaklığ $400^{\circ} \mathrm{C}$ de yapılan dökümlerde gözenek miktarı \%1,52 olarak ölçülmüştür. Ayrıca şekilde dikkat çeken bir diğer husus da kalıp sıcaklığının $200{ }^{\circ} \mathrm{C}$ 'den $300{ }^{\circ} \mathrm{C}$ 'ye artırılmasıyla dökümdeki toplam gözenek miktarı ortalama \% 0,3 seviyelerinde azalırken, $300{ }^{\circ} \mathrm{C}$ 'den $400{ }^{\circ} \mathrm{C}$ 'ye sıcaklık artışında daha az etki tespit edilmiştir.

Kalıp sıcaklığının artması ile birlikte besleme kabiliyetinin artması ve döküm parçalarda ölçülen gözenek miktarının azalması besleme yolunun daha uzun süre açık kalması ile ilişkilendirilebilir. Artan kalıp sıcaklıklarında besleme yolu daha uzun süre açık kalarak besleyicideki 
sıvı metalin döküm parçaya ulaşmasına yardımcı olmaktadır. Bu sebeple gözenek miktarı azalmıştır. Kalıp malzemesinin metal olması ve ısı iletim katsayısının yüksek olmasından dolayı katılaşma hızlı bir şekilde ilerlemiş ancak sıcaklık artışına bağlı olarak besleme yolu daha uzun süre açık kaldığ düşünülmektedir. Kalıp sıcaklığının döküm içerisinde oluşan gözenek oluşumuna etkisini incelemek için yapılan çalışmada Kısaoğlu kalıp sıcaklığının artması ile gözenek miktarının azaldığını tespit etmiştir (Akar ve ark., 2014). Ayrıca kalıp sıcaklığının artmasına bağlı olarak döküm içerisinde oluşan gözeneğin yeri besleme boğazına yaklaşmıştır. Bu da besleme boğazının daha geç katılaştığının bir göstergesidir. Bilindiği gibi çekme boşlukları en son katılaşan bölgelerde oluşmaktadır (Ravı, 2005).

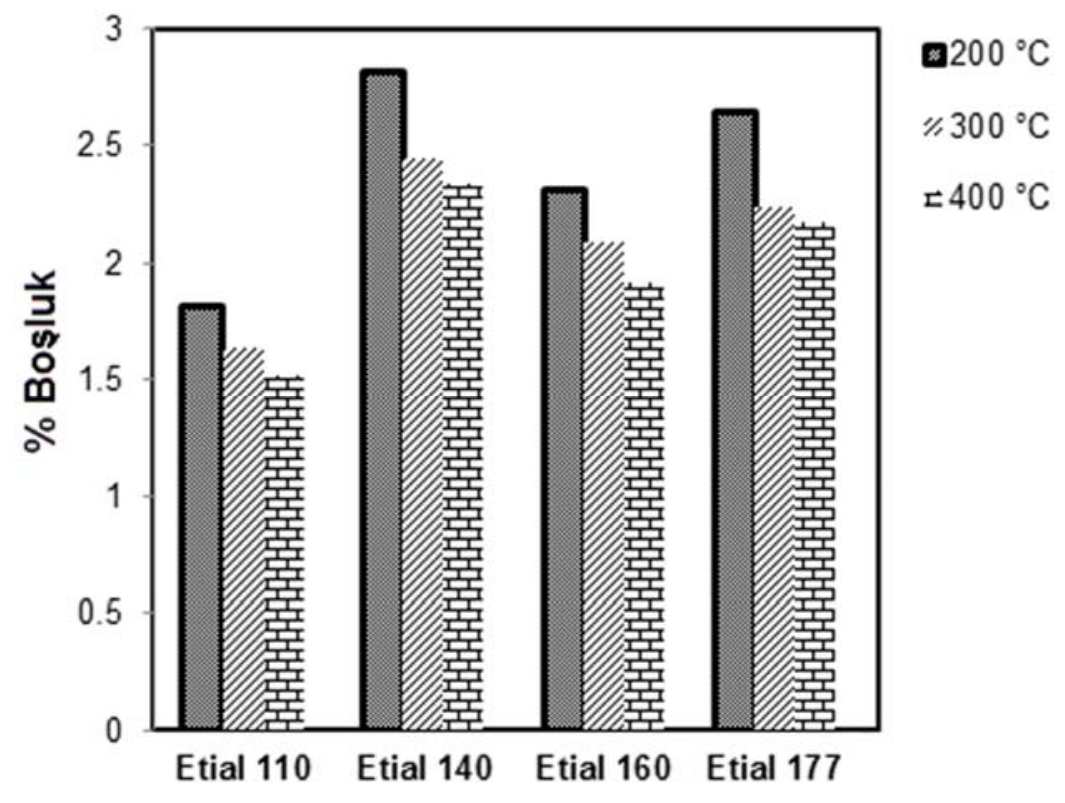

Şekil 6. Kokil kalıba döküm deneylerinde kalıp ön 1sıtma sıcaklığının gözenek oluşumuna etkisi.

\section{Sonuçlar ve Öneriler}

Bu çalışmadan elde edilen sonuçlar aşağıdaki şekilde özetlenebilir.

- Aynı geometriye sahip olsalar bile alaşım çeşidine bağlı olarak döküm parçalarda farklı oranlarda gözenek değerleri oluşabilmektedir.

-Döküm parçalar üzerinde yeterli modül ve hacim kriterine uygun besleyici olsa bile besleme yolunun kapanmasından dolayı parça üzerinde hatalar çıkabilir. Bu sebeple besleme yolunun açık kalması sağlam dökümler üretmek için dikkat edilmesi gereken önemli kriterlerden biridir.

• Gözenek ölçüm sonuçları dökümlerde oluşan gözenek oranının alaşımın katılaşma aralığı ile ters orantılı ilişki gösterdiğini ortaya koymuştur. En yüksek gözenek oranı en dar katılaşma aralığına sahip Etial 140 (ötektik Al-Si) alaşımı ile yapılan dökümlerden ölçülmüştür. Bunu karşılık en düşük 
gözenek değerleri ise kullanılan alaşımlar içinde en yüksek katılaşma aralığına sahip Etial 110 alaşımı ile yapılan dökümlerden ölçülmüştür.

-Kokil kalıba yapılan döküm deneylerinde kalıp ön 1sıtma sıcaklığının artmasının döküm içyapısında gözenek oranını azalttığı tespit edilmiştir. Bu durum daha sıcak kalıplara yapılan dökümlerde kalıp-döküm ara yüzey temasının daha yüksek olması ve buna bağlı olarak ara yüzey ısı transferinin daha yüksek değerde gerçekleşmiş olabileceği ve yüksek soğuma hızı ve yüksek gradyan etkisi ile besleme etkisinin daha uzun süre devam etmesi ile ilişkilendirilmiştir.

Bu çalışma kapsamında elde edilen sonuçlar ışı̆̆ında; alüminyum alaşımlarının dökümünde alaşımının kimyasal bileşim ve katılaşma aralığına bağlı olarak farklı oranlarda porozite ile karşılaşacağı ve üreticilerin bunu göz önüne alarak kalıplama tasarımı yapmaları önerilmektedir. Ayrıca kalıp geometrisine bağlı olarak ekonomik sınırlar içerisinde kalıp sıcaklığını artırmak sağlam parça imalatı ve porozite miktarının azaltılması için faydalı olacağı düşünülmektedir.

\section{Kaynaklar}

AKAR, N., KAYIKCI R. ve KISAOĞLU, A. K., Kokil Kalıba Dökülen Al-4,3Cu Alaşımının Kritik Katı Oranı Faktörünün Kalıp Sıcaklığı Ve Tane Boyutuna Bağlı Olarak Modellenmesi, Journal of Polytechnic, Vol: 17 No: 2 pp.83-89, 2014.

ALAN, S., Alüminyum Raporu, Orta Anadolu İhracatçı Birlikleri Genel Sekreterliği, s. 30, 2008.

CAMPBELL, J., Feeding mechanisms in casting, AFS Cast Metals, Research Journal 5, pp.1-8, 1999.

CAMPBELL, J., Casting (Second Edition),Butterworth-Heinemann, Oxford., United Kingdom,17-98, 2003.

CAMPBELL, J., Castings Practice The 10 Rules of Castings, Butterworth Heinemann,Oxford., United Kingdom, 9-113, 2004.

CHIESA, F., MAMMEN, J., Correlating Microporosity to Local Solidification Conditions and RPT in Aluminum A356 Castings, AFS Transactions, Vol.107, pp103-111, 1999.

DANYLO, B.O., DOĞAN, Ö.N., An examination of effects of solidification parameters on permeability of a mushy zone in castings, Journal of Materials Science, 43, pp.1471-1479, 2008.

DASH, M., MAKHLOUF, M., Effect of key alloying elements on the feeding characteristics of aluminumsilicon casting alloys, Journal of Light Metals, 1 pp. 251-265, 2001.

DISPINAR, D., Determination of Metal Quality of Aluminium and Its Alloys, School of Metallurgy and Materials The University of Birmingham, Doctor of Philosophy, UK, 16-25, 2005.

KAYIKCI, R., Use of Computer Modelling In Predicting Microporosity In A Commercial Aluminum Casting, 66. World Foundr Congress, İstanbul, 7-9 September 2004.

RAVI, B., Metal Casting: Computer aided designe and analysis, PHI, India 42-43, 2005.

SABAU, A.S., VISWANATHAN, S., Microporosity Prediction in Aluminum Alloy Castings, Metallurgical And Materials Transactions B, Volume 33b, 243-255, April 2002.

SHAFYEI, A., MOUSAVI, S.H.A., BAHRAMI, A., Prediction of porosity percent in Al-Si casting alloys using ANN, Materials Science and Engineerng A, 431, 1-2, 206-210, 2006.

SIGWORTH, G.K., Theoretical and partical aspects of the modification of aluminium-silicon alloys, A.F.S. Transactions 66, 1983.

SAVAŞ, Ö., (2005). Alüminyum-Silisyum Döküm Alaşımlarında Mikro Porozite Oluşumuna Etki Eden Faktörlerin İncelenmesi”, Yüksek Lisans Tezi, Sakarya Üniversitesi Fen Bilimleri Enstitüsü, Sakarya.

SCHMIDT, D.C., CFS Settings, Finite Solutions Inc Slinger WI, February 8, 2010.

TAYLOR, R.P., MCCLAIN, S.T., BERRY, J.T., Uncertainty analysis of metal-casting porosity measurements using Archimedes' principle. Int J Cast Met, 11:247-57, 1999.

URL-1: http://www.etialuminyum.com/, (Erişim Tarihi: 18.05.2018). 